\title{
Determinants of Capital Adequacy Ratio of Banks in Botswana
}

\author{
Hassan Kablay ${ }^{1}$, Victor Gumbo ${ }^{1}$ \\ ${ }^{1}$ Department of Mathematics, University of Botswana, Gaborone, Botswana \\ Correspondence: Hassan Kablay, Department of Mathematics, University of Botswana, Private Bag UB00704, Gaborone, \\ Botswana. E-mail: hassankablay@gmail.com
}

Received: September 7, 2021 Accepted: October 14, $2021 \quad$ Online Published: November 10, 2021

doi:10.5539/jmr.v13n6p38～URL: https://doi.org/10.5539/jmr.v13n6p38

\begin{abstract}
Capital Adequacy Ratio (CAR) plays a very important role in the financial success of banks and acts as a buffer to prevent and absorb any unexpected losses. This study examines explanatory variables that influence CAR for nine banks in Botswana. Multiple linear regression was used for analysis, with CAR as the dependent variable and thirteen financial ratios as the independent variables. The study period is 2015-2019. Based on the data for this period, it was established that out of the thirteen financial ratios utilised, only four were found to have significant impact on the CAR of the nine banks under study, which are: Asset to Equity Ratio (A_E), Return on Equity (ROE), Non-Performing Loans Ratio (NPL_RATIO) and the Cost-to-Income Ratio (C_I). The A_E Ratio was found to be the most influential driver of the CAR and the NPL_Ratio was found to be the least influential driver of the CAR for the banks under study.
\end{abstract}

Keywords: capital adequacy ratio, multiple linear regression, Botswana

\section{Introduction}

Capital adequacy ratio is an important measure of "Safety and Soundness", hence sufficient capital is required by banks as it acts as a buffer to prevent and absorb any unexpected losses. Mishkin (2013) states that banks have to make decisions about the amount of capital they need to hold for the following three reasons:

- Bank capital helps to prevent bank failure,

- The amount of capital affects returns for the owners (equity holders) of the bank, and

- A minimum amount of bank capital (bank capital requirements) is required by bank authorities.

Capital adequacy ratio refers to the amount of equity capital and other securities which a bank holds as reserves against risky assets. According to Basel II, CAR is measured using Tier 1 (Core Capital) and Tier 2 (Supplementary Capital). The sum of the Tier 1 Capital and Tier 2 Capital is divided by the Risk Weighted Assets (RWA) as shown in the equation below:

$$
\text { Capital Adequacy Ratio }(\mathrm{CAR})=\frac{\text { Tier } 1 \text { Capital }+ \text { Tier } 2 \text { Capital }}{\text { Risk Weighted Assets }}
$$

where,

- Tier 1 Capital is the core capital and it can absorb a reasonable amount of loss without forcing the bank to stop its trading. It includes shareholders' equity and retained earnings.

- Tier 2 Capital is the supplementary capital and it can sustain a loss if there is a liquidation. It includes subordinated loans, revaluation reserves, undisclosed reserves and general provisions.

- Risk Weighted Assets (RWA) are a key measure in risk management, and they are used to determine the minimum amount of capital that must be held by banks in order to reduce the risk of insolvency. Banks can increase their capital adequacy ratios by either increasing the amount of regulatory capital held, or by decreasing their RWA (Das \& Amadou, 2012). RWA include credit risk, operational risk and market risk. 
Credit Risk: This involves inability or unwillingness of a customer or counterparty to meet commitments in relation to lending, trading, hedging, settlement and other financial transactions (Spuchláková, Valasková, \& Adamko, 2015).

Operational Risk: The risk of loss resulting from inadequate or failed internal processes, people, and systems or from external events (Federal Deposit Insurance Company, 2006).

Market Risk is the risk of loss resulting from changes in the prices of instruments such as bonds, share and currencies (Basel Committee on Banking Supervision, 2019).

The Central Bank of Botswana, Bank of Botswana (BOB), requires all banks in the country to maintan a capital adequacy ratio at or above 15 percent (Bank of Botswana, 2019). Majority of banks in Botswana are well capitalised, hence they have the ability to continue to honor their obligations.

The main objective of this paper is to analyse the determinants of CAR for nine banks in Botswana. The study covers the period 2015 to 2019. The study is divided into six sections, the Introduction in Section 1, followed by the Literature Review in Section 2, Definition of Variables in Section 3, The Modelling Approach is discussed in Section 4, Back Testing and Model Accuacy Test in Section 5, and finally section 6 will illustrate the Discussion of the Results and Conclusion.

\section{Literature Review}

El-Ansary and Hafez (2015) carried out a study to investigate the determinants of capital adequacy ratio on commercial banks in Egypt for the period 2003-2013 using multiple linear regression analysis. Some of their major findings were that, profitability had no impact on CAR, however, return on assets was found to be significantly positively correlated to CAR. Liquidity and management quality were found to be positively correlated to CAR while size of bank and risk was found to be negatively correlated to CAR. Asset quality was not correlated to CAR. Al-Tamini and Obeidat (2013) examined the factors that determine capital adequacy of commercial banks in Jordan for the period 2000-2008. Some of the major findings were that there was a statistically significant positive correlation between capital adequacy of commercial banks and liquidity risk, as well as rate of return on assets. Moreover, in their study they found out that there is an inverse relationship with statistical significance between capital adequacy and rate of return on equity and interest rate risk. In a study by Kartal (2019), the factors that influence CAR in the Turkish Banking Sector (TBS) for the period 2006/Q1 2019/Q1 were studied using Multivariate Adaptive Regression Splines (MARS) on 14 explanatory variables. It was found out that credits/total asset ratio, legal equities, risk weighted assets, non performing loans (NPL), NPL/total credits ratio and credit/deposits ratio were influential factors on CAR in Turkey.

Using panel data regression, Raharjo, Hakim, Manurung, and Maulana (2014) studied the determinants of capital ratio of the state-owned banks in Indonesia and it was established that the capital ratio was affected by the size of the bank, the bank's leverage, the quality of management, and the interest rate risk. Bhattarai (2020) carried out a study to determine the CAR of 11 commercial banks in Nepal for the period 2013/14 to 2017/18. The Pooled OLS, Fixed Effects Model and Random Effects Model were used for data analysis and it was established that liquidity, size of bank and inflation were the major determinants of CAR in Nepal with liquidity having a positive and statistically significant effect, whereas the size of the bank and inflation rate had negative and statistically significant results.

Soelton et al. (2019) studied the effect of CAR, operating expense, Net Interest Margin and Non Performing Loans on the Loan to Deposit ratio of conventional banks in Indonesia Stock Exchange. The study period was 2012-2017 and the analytical tool used was multiple linear regression analysis and one of the major findings was that CAR insignificantly negatively influences the Loan to Deposit ratio. Unvan (2020) investigated the effect of bank specific and macroeconomic factors on CAR of banks in Ghana for the period 2008-2017 using Generalized Method of Moments (GMM). It was established that bank size, leverage and broad money supply significantly influence the capital adequacy level of banks. Moreover, it was found out that bank profitability positively influences capital adequacy but at an insignificant level. Bateni, Vailifard, and Asghari (2014) examined the influence of seven financial factors on capital adequacy of Iranian banks for the period 2006-2012 and some of the major findings were that there is a positve relationship between Loan Asset Ratio, ROE, ROA, Equity Ratio and CAR.

El-Ansary, El-Masry, and Yousry (2019) carried out a comparative analysis of CAR determinants between 38 Islamic Banks (IBs) and 75 Conventional Banks (CBs) in MENA countires using GMM. CAR was used as the dependent variable and profitability, liquidity risk, credit risk, bank size, deposits to assets, operational efficiency, portfolio risk and two macro-economic variables as independent variables. In their study, it was found out that both Islamic banks and Conventional Banks have a significant association between CAR and bank size, operational efficiency and DP growth rate. A significant association between CAR and Deposits to Assets ratio was seen for IBs, while for CBs it was found out that there is an association between CAR and profitability, credit risk and portfolio risk. Alajmi and Alqasem (2015) studied the effects of seven internal factors on capital adequacy ratios of five conventional banks in Kuwaiti for the period 2005 to 2013 using fixed effect model and random effect model. When using the fixed effect model, it was found out 
that size and ROA have a significant and negative relationship with CAR whereas the other five factors did not have any impact on CAR. When using the random effect model, it was found out that CAR was adversely affected by bank size and ROA was found to have a significant and positive relationship with CAR, whereas, LDR showed a significant and positive relationship with CAR. The other four factors did not have a significant effect on CAR.

Dreca (2013) examined the influence of eight factors on the CAR of 10 banks in Bosnia and Herzegovina for a study period of 6 years. Some of the major findings were that Size, Deposit to Total Asset ratio, Loans to Total Assets, Return on Assets, Return on Equity and Equity to Total Liabilities ratio had a significant effect on CAR while Loan Loss Provision to Total Loans ratio and Net Interest Income to Total Assets did not have a significant effect on CAR. Aktas, Acikalin, Bakin and Celi (2015) carried out a study to evaluate the impact of bank-dimensional and environmental factors on bank's capital adequacy ratio for 71 commercial banks that belong to 10 different countries in South Eastern European (SEE) region for the period 2007-2012. It was found out that under bank dimensional explanatory variables, the size, ROA, leverage, liquidity, net interest margin and risk have statistically significant effects in determining CAR, while under environmental factors, the economic growth rate, Eurozone Stock Market Volatility index, Deposit Insurance Coverage and Governance have statistically significant effect in determining CAR for banks in the region under study. Thoa and Anh (2017) examined the relationship between six internal banking factors (independent variables) and CAR (dependent variable) in the Vietnamese banking system. The study was carried out using linear regression analysis and the study period was 2011-2015. Some of the findings in the study were that, bank size and leverage have no impact on the CAR, while the net interest margin and liquidity have a siginificant positive impact on CAR.

\section{Definition of Variables}

When using multiple linear regression, the goal is to predict the dependent variable, which in this study is defined as:

$$
\text { - } \mathrm{Y}=\mathrm{CAR}=(\text { Tier } 1 \text { Capital }+ \text { Tier } 2 \text { Capital }) / \text { Risk Weighted Assets }
$$

The independent variables $X_{i}$ are:

- $\mathrm{X} \_1=$ A_E $=$ Assets $/$ Equity

- $\mathrm{X} \_2=\mathrm{C}_{-} \mathrm{I}=$ Operating Expenses $/$ Operating Income

- X_3 = CA_TA = Circulating Assets $/$ Total Assets

- X_4= IE_A= Interest Expense/ Assets

- X_5= II_AVG_TA= Interest Income on Loans/ Average Total Assets

- X_6= II_IE = Interest Income / Interest Expense

- $\mathrm{X}_{-} 7=\mathrm{LDR}=$ Loans/ Deposits

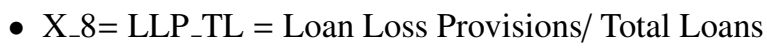

- X_9= NET_II_TI = Net Interest Income / Total Income

- X_10= NII_TI = Non-Interest Income $/$ Total Income

- X_11 = NIM = Net-Interest Income / Average Assets

- $\mathrm{X}_{-} 12=$ NPL_Ratio $=$ Non Performing Loans $/$ Gross Advances

- X_13= ROE = Net Profit after Taxes $/$ Equity

\section{The Modelling Approach}

The study was based on 9 banks in Botswana and the data sources were their annual reports and financial statements. The 9 banks are; ABSA (formerly Barclays), Stanbic Bank Botswana, First National Bank Botswana, BancABC, State Bank of India, First Capital Bank, Bank Gaborone, Standard Chartered Bank Botswana and Bank of Baroda. The study period was 2015 to 2019. 


\subsection{Data Analysis}

\subsubsection{Descriptive Statistics}

The descriptive statistics (mean, minimum, maximum, standard deviation, variance and skewness) for all the variables are shown in Table 1 . The banks under study have an average CAR of about $20.81 \%$, which is above the $15 \%$ required by the Bank of Botswana.

Table 1. Descriptive Statistics

\begin{tabular}{|c|c|c|c|c|c|c|c|c|c|}
\hline & $\mathrm{N}$ & & Minimum & Maximum & Mean & $\begin{array}{ll}\text { Std. Devia- } \\
\text { tion }\end{array}$ & Variance & Skewness & \\
\hline & Statistic & & Statistic & Statistic & Statistic & Statistic & Statistic & Statistic & Std. Error \\
\hline CAR & & 45 & 0.1520 & 0.4181 & 0.2081 & 0.0590 & 0.0035 & 2.1041 & 0.3537 \\
\hline A_E & & 45 & 3.4373 & 19.4935 & 9.9167 & 3.4276 & 11.7487 & 0.2539 & 0.3537 \\
\hline C_I & & 45 & 0.3176 & 2.1794 & 0.6866 & 0.3072 & 0.0944 & 3.1703 & 0.3537 \\
\hline CA_TA & & 45 & 0.0325 & 0.3839 & 0.1244 & 0.0875 & 0.0077 & 1.2127 & 0.3537 \\
\hline IE_A & & 45 & 0.0065 & 0.0695 & 0.0253 & 0.0128 & 0.0002 & 1.3810 & 0.3537 \\
\hline II_AVG_TA & & 45 & 0.0301 & 0.1004 & 0.0636 & 0.0154 & 0.0002 & 0.5198 & 0.3537 \\
\hline II_IE & & 45 & 1.4789 & 6.9847 & 3.1742 & 1.3342 & 1.7800 & 1.2594 & 0.3537 \\
\hline LDR & & 45 & 0.1624 & 1.0934 & 0.8302 & 0.1604 & 0.0257 & -1.6114 & 0.3537 \\
\hline LLP_TL & & 45 & -0.0033 & 0.0570 & 0.0115 & 0.0109 & 0.0001 & 1.8981 & 0.3537 \\
\hline NET_II_TI & & 45 & 0.4328 & 0.8124 & 0.6558 & 0.1041 & 0.0108 & -0.2988 & 0.3537 \\
\hline NII_TI & & 45 & 0.1876 & 0.5672 & 0.3442 & 0.1041 & 0.0108 & 0.2988 & 0.3537 \\
\hline NIM & & 45 & 0.0190 & 0.0724 & 0.0434 & 0.0139 & 0.0002 & 0.4212 & 0.3537 \\
\hline NPL_RATIO & & 45 & 0.0000 & 0.0898 & 0.0434 & 0.0217 & 0.0005 & -0.0675 & 0.3537 \\
\hline ROE & & 45 & -0.2109 & 0.2512 & 0.1105 & 0.1049 & 0.0110 & -0.9499 & 0.3537 \\
\hline Valid N (listwise) & & 45 & & & & & & & \\
\hline
\end{tabular}

\subsubsection{Multicollinearity Test}

The dependent and independent variables are tested for multicollinearity using the correlation matrix shown in Table 2 and it was established that there was no significant correlation between CAR and the 13 independent variables.

Table 2. Correlation Analysis

\begin{tabular}{|c|c|c|c|c|c|c|c|c|c|c|c|c|c|c|}
\hline & $C A R$ & $A \_E$ & $C \_I$ & CA_TA & $I E A$ & $I I \_$$A V G_{-} T A$ & II_IE & $L D R$ & $L L P \_T L$ & $N E T \_I I \_T I$ & NII_TI & NIM & $N P L \_R A T I O$ & $R O E$ \\
\hline CAR & 1 & & & & & & & & & & & & & \\
\hline A_E & -0.6663 & 1 & & & & & & & & & & & & \\
\hline C_I & 0.2795 & -0.0694 & 1 & & & & & & & & & & & \\
\hline IE_A & 0.0853 & 0.0446 & 0.2985 & -0.1322 & 1 & & & & & & & & & \\
\hline II_AVG_TA & -0.4903 & 0.1906 & -0.3406 & 0.1229 & 0.2304 & 1 & & & & & & & & \\
\hline II_IE & -0.0803 & -0.2814 & -0.1618 & 0.0412 & -0.6875 & 0.1106 & 1 & & & & & & & \\
\hline LDR & -0.3070 & 0.2507 & -0.5886 & -0.3686 & -0.1010 & 0.3887 & 0.1914 & 1 & & & & & & \\
\hline NET_II_TI & 0.1799 & -0.1563 & 0.0803 & -0.0298 & 0.3134 & 0.3644 & -0.1469 & -0.2549 & -0.0582 & 1 & & & & \\
\hline NII_TI & -0.1799 & 0.1563 & -0.0803 & 0.0298 & -0.3134 & -0.3644 & 0.1469 & 0.2549 & 0.0582 & -1.0000 & 1 & & & \\
\hline NIM & 0.0179 & -0.3531 & -0.1843 & 0.0074 & -0.0326 & 0.4851 & 0.5836 & 0.3029 & 0.0420 & 0.2174 & -0.2174 & 1 & & \\
\hline NPL_RATIO & -0.4205 & 0.1829 & -0.5701 & 0.3598 & -0.2858 & 0.2700 & 0.1719 & 0.1182 & 0.5131 & 0.0708 & -0.0708 & -0.0967 & 1 & \\
\hline ROE & -0.4042 & -0.0848 & -0.5778 & 0.2990 & -0.4183 & 0.4337 & 0.4904 & 0.4397 & -0.1146 & -0.2406 & 0.2406 & 0.3933 & 0.1961 & 1 \\
\hline
\end{tabular}

\subsection{Multiple Regression Analysis}

The general CAR model is:

$$
C A R=\beta_{0}+\sum_{i} \beta_{i} * X_{i}+\mu
$$


where;

- $i$ ranges from 1 to 13 ,

- $\beta_{0}$ is the constant term to be determined,

- $\beta_{i}$ are the coefficients to be determined,

- $X_{i}$ is the $i^{\text {th }}$ driver of CAR,

- $\mu$ is a random error.

Table 3. Estimation of parametes for CAR Model

\begin{tabular}{|c|c|c|c|c|c|c|c|c|c|c|}
\hline \multirow{2}{*}{\multicolumn{2}{|c|}{ Model }} & \multicolumn{2}{|c|}{ Unstandardized Coefficients } & \multirow{2}{*}{$\begin{array}{l}\begin{array}{l}\text { Standardized } \\
\text { Coefficients }\end{array} \\
\text { Beta } \\
\end{array}$} & \multirow[t]{2}{*}{$\mathrm{t}$} & \multirow[t]{2}{*}{ Sig. } & \multicolumn{2}{|c|}{ 95.0\% Confidence Interval for B } & \multicolumn{2}{|c|}{ Collinearity Statistics } \\
\hline & & B & Std. Error & & & & Lower Bound & Upper Bound & Tolerance & VIF \\
\hline & (Constant) & 0.4379 & 0.0316 & & 13.8591 & 0.0000 & 0.3740 & 0.5017 & & \\
\hline & A_E & -0.0115 & 0.0014 & -0.6692 & -8.0916 & 0.0000 & -0.0144 & -0.0086 & 0.9501 & 1.0525 \\
\hline \multirow[t]{3}{*}{1} & ROE & -0.3155 & 0.0571 & -0.5610 & -5.5248 & 0.0000 & -0.4309 & -0.2001 & 0.6302 & 1.5869 \\
\hline & NPL_RATIO & -0.9682 & 0.2756 & -0.3557 & -3.5127 & 0.0011 & -1.5253 & -0.4111 & 0.6339 & 1.5776 \\
\hline & C_I & -0.0564 & 0.0231 & -0.2939 & -2.4419 & 0.0191 & -0.1031 & -0.0097 & 0.4485 & 2.2294 \\
\hline
\end{tabular}

a. Dependent Variable: CAR

The CAR model is::

$$
\begin{aligned}
C A R= & 0.4379-0.0115 * A_{-} E-0.3155 * R O E \\
& -0.9682 * N P L \_R A T I O-0.0564 * C_{\_} I
\end{aligned}
$$

From the CAR model and Table 3, it is evident that A_E, ROE, NPL_RATIO and C_I are the most influential drivers of CAR for the banks under study. It was also established that A_E is the largest driver with a coefficient of -0.0115 , therefore for every 1-unit increase in A_E, there is a 0.0115 decrease in CAR, assuming all other variables are held constant. Therefore, A_E and CAR are negatively correlated. The least influential driver with a coefficient of -0.9682 is NPL_RATIO, meaning that for every 1-unit increase in NPL_RATIO there is a 0.9682 decrease in CAR, assuming all other variables are held constant. Therefore, the NPL_RATIO and CAR are negatively correlated. In the absence of all drivers, banks in Botswana generally have a CAR of $43.79 \%$ as derived from the constant of 0.4379 in the CAR model above.

The $R^{2}$ and adjusted $R^{2}$ values of $74.0 \%$ and $71.4 \%$, respectively, shown in Table 4 indicate a good explanatory power for the regression model, as the $R^{2}$ value shows that $74.0 \%$ of the variation in the dependent variable (CAR) is explained by the independent variables. The same applies for the adjusted $R^{2}$ value, that is, $71.4 \%$ of the variation in the dependent variable (CAR) is explained by the independent variables.

Table 4. Model Summary

\begin{tabular}{lcrrr}
\hline Model & R & R Square & Adjusted R Square & Std. Error of the Estimate \\
\hline 1 & 0.8600 & 0.7401 & 0.7141 & 0.0315 \\
\hline
\end{tabular}

a. Predictors: (Constant), A_E, ROE, NPL_RATIO, C_I

b. Dependent Variable: CAR

As shown in Table 5, the model has a significance value $=0.000<0.05$ (chosen significance level). This implies that the model is significant at the chosen level of significance of 5\%. Therefore, A_E, ROE, NPL_RATIO and C_I have a significant impact on the CAR of the 9 banks in this study. 
Table 5. ANOVA

\begin{tabular}{|c|c|c|c|c|c|c|}
\hline \multicolumn{2}{|c|}{ Model } & \multirow{2}{*}{$\begin{array}{r}\text { Sum of Squares } \\
0.1132\end{array}$} & \multirow{2}{*}{$\frac{\mathrm{df}}{4}$} & \multirow{2}{*}{$\begin{array}{r}\text { Mean Square } \\
0.0283\end{array}$} & \multirow{2}{*}{$\frac{F}{28.4713}$} & Sig. \\
\hline & Regression & & & & & 0.0000 \\
\hline \multirow[t]{2}{*}{1} & Residual & 0.0398 & 40 & 0.0010 & & \\
\hline & Total & 0.1530 & 44 & & & \\
\hline
\end{tabular}

\section{Back Testing and Model Accuracy Test}

\subsection{Back Testing}

The model was back-tested using a data set compiled from 2015-2019 and the results in Table 6 were obtained. The model was able to predict the CAR for all the banks with an average error of $0.70 \%, 0.33 \%, 0.34 \%,-0.27 \%$ and $-1.11 \%$ for 2015 , 2016, 2017, 2018 and 2019, respectively. On average, for the study period, the model performed the best on 2018 data with an average error of $-0.27 \%$ and performed the least on 2019 data with an average error of $-1.11 \%$. Using the 5 year average, the model was found to be most accurate when predicting the ABSA performance followed by Bank of Baroda, and the least accuracy was noted when predicting the CAR for BancABC.

Table 6. Back Testing

\begin{tabular}{|c|c|c|c|c|c|c|c|c|c|c|c|c|c|c|c|c|}
\hline \multirow[b]{2}{*}{ Bank Name } & \multicolumn{5}{|c|}{ Actual CAR } & \multicolumn{5}{|c|}{ Predicted CAR } & \multicolumn{5}{|c|}{ Error } & \multirow{2}{*}{ Average Error (5 Years) } \\
\hline & 2015 & 2016 & 2017 & 2018 & 2019 & 2015 & 2016 & 2017 & 2018 & 2019 & 2015 & 2016 & 2017 & 2018 & 2019 & \\
\hline ABSA (formerly Barclays) & $19 \%$ & $20 \%$ & $19 \%$ & $18 \%$ & $19 \%$ & $20 \%$ & $18 \%$ & $20 \%$ & $18 \%$ & $18 \%$ & $1 \%$ & $-1 \%$ & $1 \%$ & $1 \%$ & $-1 \%$ & $-0.02 \%$ \\
\hline Banc ABC & $16 \%$ & $20 \%$ & $20 \%$ & $18 \%$ & $19 \%$ & $19 \%$ & $20 \%$ & $24 \%$ & $20 \%$ & $21 \%$ & $3 \%$ & $0 \%$ & $4 \%$ & $2 \%$ & $2 \%$ & $2.22 \%$ \\
\hline Bank Gaborone & $18 \%$ & $17 \%$ & $18 \%$ & $17 \%$ & $16 \%$ & $20 \%$ & $16 \%$ & $16 \%$ & $16 \%$ & $14 \%$ & $2 \%$ & $-2 \%$ & $-2 \%$ & $-1 \%$ & $-2 \%$ & $-0.80 \%$ \\
\hline Bank of Baroda & $23 \%$ & $25 \%$ & $22 \%$ & $30 \%$ & $27 \%$ & $25 \%$ & $25 \%$ & $26 \%$ & $29 \%$ & $23 \%$ & $2 \%$ & $0 \%$ & $4 \%$ & $-1 \%$ & $-4 \%$ & $0.05 \%$ \\
\hline First Capital Bank & $17 \%$ & $19 \%$ & $16 \%$ & $15 \%$ & $20 \%$ & $22 \%$ & $16 \%$ & $20 \%$ & $14 \%$ & $17 \%$ & $5 \%$ & $-3 \%$ & $4 \%$ & $-1 \%$ & $-3 \%$ & $0.51 \%$ \\
\hline First National Bank & $19 \%$ & $16 \%$ & $18 \%$ & $18 \%$ & $17 \%$ & $19 \%$ & $19 \%$ & $18 \%$ & $18 \%$ & $18 \%$ & $0 \%$ & $3 \%$ & $1 \%$ & $0 \%$ & $1 \%$ & $0.98 \%$ \\
\hline Stancbic Chartered Bank Botswana & $24 \%$ & $18 \%$ & $19 \%$ & $17 \%$ & $18 \%$ & $19 \%$ & $18 \%$ & $19 \%$ & $17 \%$ & $19 \%$ & $-6 \%$ & $0 \%$ & $0 \%$ & $0 \%$ & $1 \%$ & $-0.81 \%$ \\
\hline Standard Chartered & $20 \%$ & $22 \%$ & $16 \%$ & $21 \%$ & $19 \%$ & $21 \%$ & $19 \%$ & $16 \%$ & $18 \%$ & $19 \%$ & $2 \%$ & $-3 \%$ & $0 \%$ & $-3 \%$ & $0 \%$ & $-1.05 \%$ \\
\hline & & erag & rror & (Yearl) & & & & & & & $0.70 \%$ & $33 \%$ & $.34 \%$ & $.27 \%$ & $.11 \%$ & \\
\hline
\end{tabular}

\subsection{Model Accuracy Test}

The performance of the model in predicting the CAR of the banks under study was measured using the Mean Absolute Error (MAE), Mean Square Error (MSE) and Root Mean Square Error (RMSE). The model was found to perform well and the results are shown on Table 7.

Table 7. Model Accuracy Test

\begin{tabular}{cr}
\hline \multicolumn{2}{c}{ Model Accuracy Metrics } \\
\hline MAE & $2.19 \%$ \\
MSE & $0.09 \%$ \\
RMSE & $2.97 \%$ \\
\hline
\end{tabular}

\section{Discussion of the Results and Conclusion}

The research analyses the influence of thirteen financial ratios on the capital adequacy ratio of nine banks in Botswana. Asset to Equity Ratio (A_E), Return on Equity (ROE), Non-Performing Loans Ratio (NPL_RATIO) and Cost to Income Ratio (C_I) were found to be the most influential drivers of the CAR in Botswana banks. The NPL ratio was found to be an influential driver of the CAR for the banks under study, which is in agreement with the study by Kartal (2019). The ROE, being one of the most influential drivers, is in agreement with Al-Tamini and Obeidat (2013), who found out that there is an inverse relationship between the capital adequacy and rate of return on equity. The A_E Ratio was found to be the most influential driver of the CAR for the banks under study. For the study period, the model performed the best on 2018 data with an average error of $-0.27 \%$ and performed the least on 2019 data with an average error of $-1.11 \%$. Using the 5 year average, the model was found to be most accurate when predicting the ABSA performance followed by Bank 
of Baroda, and the least accuracy was noted when predicting the CAR for BancABC. The model was found to perform well with a MAE of $2.19 \%$, a MSE of $0.09 \%$ and a RMSE of $2.97 \%$.

\section{References}

Mishkin, F. S. (2013). The Economics of Money, Banking, and Financial Markets (10th ed.). Pearson Education.

Sonali, D., \& Amadou, N. R. (2012). How Risky Are Banks' Risk Weighted Assets? Evidence From the Financial Crisis. IMF Working Papers, 12(36). https://papers.ssrn.com/sol3/papers.cfm?abstract_id=1997749

Spuchláková, E., Valasková, K., \& Adamko, P. (2015). The Credit Risk and its Measurement, Hedging and Monitoring. Procedia Economics and Finance, 24, 675-681. https://doi.org/10.1016/s2212-5671(15)00671-1

Federal Deposit Insurance Corporation. (2006). Supervisory Insights. Federal Deposit Insurance Corporation, 3(1). https://www.fdic.gov/regulations/examinations/supervisory/insights/sisum06/sisummer06-article1.pdf

Basel Committee on Banking Supervision. (2019). The Market Risk Framework In brief. Basel Committee on Banking Supervision. https://www.bis.org/bcbs/publ/d457_inbrief.pdf

Bank of Botswana. (2019). Banking Supervision Annual Report 2019. Bank of Botswana. https://www.bankofbotswana.bw/publication/banking-supervision-annual-report-2019

El-Ansary, O. A., \& Hafez, H. M. (2015). Determinants of Capital Adequacy Ratio: An Empirical Study on Egyptian Banks. Corporate Ownership \& Contol, 13(4), 806-816.

Al-Tamimi, K. A. M., \& Obeidat, S. F. (2013). Determinants of Capital Adequacy in Commercial Banks of Jordan an Empirical Study. International Journal of Academic Research in Economics and Management Sciences, 2(4). https://doi.org/10.6007/IJAREMS/v2-i4/53

Kartal, M. T. (2019). Defining Influential Factors of Capital Adequacy Ratio: An Examination upon Turkish Banking Sector (2006/Q1-2019/Q1). Emerging Markets Journal, 9(2). http://dx.doi.org/10.2139/ssrn.3644679

Raharjo, P. G., Hakim, D. B., Manurung, A. H., \& Maulana, T. N. A. (2014). Determinants of Capital Ratio: A Panel Data Analysis on State-Owned Banks in Indonesia. Bulletin of Monetary, Economics and Banking, 16(4). https://doi.org/10.21098/bemp.v16i4.451

Bhattarai, B. P. (2020). Determinants of Capital Adequacy Ratio of Commercial Banks in Nepal. Asian Journal of Finance $\mathcal{E}$ Accounting, 12(1). https://doi.org/10.5296/ajfa.v12i1.17521

Soeltan, M., Wahyono, T., Trydianto, O., Suzabar, D. F., Akbar, T., \& Mardaconsita (2019). Analysis of Capital Adequacy Ratio, Operational Costs of Operational Income, Net Interest Margin, and Non-Performing Loan towards Loan to Deposit Ratio in Go Public Conventional Banks, 2012-2017 Periods. International Journal of Economics and Financial Research, 5(3), 56-60.

Unvan, Y. A. (2020). Determinants of Capital Adequacy Ratio in Ghana. Journal of Yasar University, 15(58), 160-166. https://doi.org/10.19168/jyasar.655952

Bateni, L., Vailifard, H., \& Asghari, F. (2014). The Influential Factors on Capital Adequacy Ratio in Iranian Banks. International Journal of Economics and Finance, https://doi.org/10.5539/ijef.v6n11p108

El-Ansary, O., El-Masry, A. A., \& Yousry, Z. (2019). Determinants of Capital Adequacy Ratio (CAR) in MENA Region: Islamic vs Conventional Banks. International Journal of Accounting and Financial Reporting, 9(2). https://doi.org/10.5296/ijafr.v9i2.14696

Alajmi, M., \& Alqasem, K. (2015). Determinants of Capital Adequacy Ratio in Kuwaiti Banks. Journal of Governance and Regulaton, 4(4), 315-322.

Dreca, N. (2013). Determinants of Capital Adequacy Ratio in Selected Bosnian Banks. Dumplupinar Universitesi Sosyal Bilimier Dergisi, 4(4), 149-162.

Aktas, R., Acikalin, S., Bakin, B., \& Celi, G. (2015). The Determinants of Banks' Capital Adequacy Ratio: Some Evidence from South Eastern European Countries. Journal of Economics and Behavioural Studies, 7(1), 79-88. https://doi.org/10.22610/jebs.v7i1(J).565

Thoa, P. T. X., \& Anh, N. N. (2017). The Determinants of Capital Adequacy Ratio: The Case of the Vietnamese Banking System in the Period 2011-2015. Journal of Science: Economis and Business, 33(2), 49-58. 
https://doi.org/10.25073/2588-1108/vnueab.4070

\section{Copyrights}

Copyright for this article is retained by the author(s), with first publication rights granted to the journal.

This is an open-access article distributed under the terms and conditions of the Creative Commons Attribution license (http://creativecommons.org/licenses/by/4.0/). 